\title{
Ongoing Moral Formation Of Priests
}

\author{
Rev. Dr. Pius T. T. Ajiki \\ Department of Religion \& Philosophy \\ Benue State University, Makurdi Nigeria.
}

\begin{abstract}
A generation has now elapsed after the Second Vatican Council, but for most priests ordained before or during the Council, the great surprise of John XIII awakened a sense of anticipation and hope unprecedented during their lifetimes. Bishops also feel the excitement as they reclaimed their ancient identity as members of the college of Bishops (Cozzens 129). This new identity for the priests buoyed up the church and challenged it to bring the Gospel to the crossroads and networks of the global village. The Post Conciliar Church has called for a different way of being a priest, as we witness today. One of the ways the ministry of the priest has changed is obviously the authority crisis as exemplified in the current Ahiara Diocesan Clergies' rejection of their Bishop, Most Reverend Peter Ebere0kpaLeke. This paper discusses the Ongoing Moral Formation of Priests, and recommends that for effective ministry of the priesthood, there is need to enter into crisis like many world leaders have and came out leaving behind examples for the future generations. Moses entered into crisis and led the Israelites out of slavery. So also Gandhi in India, Martin Luther King Jr. and in our time, Nelson Mandela of South Africa came out leading his people to freedom. Nigeria priests and the Catholic Church is in crisis. Emmanuel, God who is with us, Christ Jesus, should lead us to be ambassadors of reconciliation in his Church.
\end{abstract}

Key word: Ongoing Moral Formation of Priests.

\section{INTRODUCTION}

It is pertinent to note that the whole work of priestly formation would be deprived of its necessary foundation if it lacked a suitable human (moral)formation. The priest, who is called to be a living image of Jesus Christ, head and shepherd of the Church, should seek to reflect in himself, as far as possible, the human perfection which shines forth in the Incarnate Son of God and which is reflected with particular liveliness in his attitude towards others as we see narrated in the Gospel... In order that his ministry may be humanly as credible and acceptable as possible, it is important that the priest should mold his human personality in such a way that it becomes a bridge and not an obstacle for others in their meeting with Jesus Christ (Pastores Dabo Vobis No.43)

The foregoing comes from the apostolic exhortation of Pope John Paul II, Pastores Dabo Vobis, and is perhaps the most quoted passage of that entire providential document. Commentators speculate that this statement was considered almost revolutionary by many because, although the Church had presumed it for centuries, no Pope had ever stated it so officially or bluntly. The Holy Father is simply declaring the primary importance of human and moral formation in the whole enterprise of priestly preparation that a candidate for holy orders must develop human, natural virtues in addition to supernatural ones, that our personality, our humanity, our temperament, our character, constitute the matter of our priesthood, what the Lord "reorders" and uses in the sacrament of holy orders and that our personality, our temperament, our character, as priests, either attracts people to Jesus and his Church, or drives them away (Dolan 145). 
This paper seeks to underscore the import of the moral formation of ordained priests from a Catholic perspective, by bringing out the moral traditions, obedience to ordination promises, the moral rights of priests and the need to avail of the ICT for evangelization and above all, the personal efforts to a life of prayer and fasting to purify our Priestly Ministry.

\section{BACKGROUND TO CATHOLIC MORAL TEACHING}

Looking at Catholic moral teaching and traditions, it is important to note that the teaching of the magisterium in morals differs from its teaching in matters of faith (Lewis 5). As Rigali points out, the sole source of Christian faith is revelation and therefore the magisterium stands in direct relation to the entirety of faith. Clearly, however, morality does not have its only source in revelation. It is borne by all in whom conscience has been awakened and so is a shared responsibility of the human family, not an exclusive responsibility of the Church. Since the magisterium does not have a direct relation to morals in their entirety, it does not have the competence to answer all moral questions (121). Conscience bears witness to our actions (Rom 2:15)

There are three elements that enter into every religion: faith, spiritual life, and morality; creed, cult, and code (liturgy); or words, worship, and works. They correspond to the three parts of every human soul: mind, heart, and will. All three are equally central to being a Catholic. The three parts do not come separately but simultaneously. Catholics do not first decide what to believe, then move on to prayer and worship, and then begin to live morally (Kreeft 5). The order is sometimes the reverse: for the most usual source of a loss of faith is an immoral life, and the most powerful source of a moral life is prayer and the sacraments and the more prayer, the more virtue; the more virtue, the more faith (6). A priest that has time for personal prayer life will advance in morals and grace will transform his nature. But if a priest doesn't pray, the holy order will not alter your habits of life (146).

Recently, I asked a classmate of mine about one of the priests and he was curious to know why I was asking for him. He simply said the guy was transferred. I found out that this priest had become used to drinking, drive for women, money and business that it consumed his time and none even for his parishioners. Such attitudes can incapacitate our ministry and will rather drive people away than bringing them to Christ. Other priests have no problem with their human formation, but they exhibit qualities strange enough to keep fellow brothers away from them. For example, no socialization with fellow priests, no visits, not returning calls, and home until $10-11: 00$ p.m. or sometimes 12:00 a.m. Not dressing properly at home and when stepping out for meetings with parishioners and outsiders, there was no moment requesting them to join him in prayer while visiting or travelling with others.

It is therefore necessary for us to be aware of those characters and traits which do not seem to draw God's people to Jesus and the Church but rather scandalize people.

On the other hand, most of us as young men growing up and even as priests were influenced by the charitable simple hearted, sincere and compassionate priests whose lives became a gospel message for our entire life. Many lay men and women were converted to deeper Christian life due to the good and spirit filled character of some priests they met in life, why not now?

It is worthy of note that just as the Holy Eucharist is not just a rite or symbol, but Christ himself, so the moral life of the Christian is Christ himself living his life in his people. We are his own "Body!" Christ is present in our moral life in a way different from the way he is present in the Eucharist, of course: mixed with human imperfections, so that we do not worship good men/women or good deeds, as we worship the Eucharist. But the moral life of the Christian is 
not simply a human effort to imitate Christ; it is what Saint Paul called "the mystery of Christ in you, the hope of glory" (Colossians 4:3). Emphasis must also be made of the fact that Catholic Christian morality is not merely a means to the end of a better world, or peace and justice, or the welfare of the family, or social harmony although all of these are very good; these are however relative to Christ, not Christ relative to them (7).

\section{CATHOLIC MORAL TEACHING IS CONSISTENT WITH CATHOLIC}

theology (beliefs). And that theology teaches what God has revealed. And the primary data of this revelation come from Scriptures. And Scriptures tell us that right morality, not just right theology, is the main source of God's blessings (14). This point is repeated constantly in Scriptures - by Moses (Deuteronomy 30), by David(Psalm 1), and by Christ (Matthew 25).

It is interesting to point here that the 2000-year-long historical narrative of the Old Testament proves one unmistakably clear principle. That whenever God's people obey his laws, they are blessed; whenever they disobey, they are punished, to bring them to repentance and obedience and then blessing again. The same principle is clear in the history of the Church, the New Israel. In the first few centuries, it was a Church of saints and martyrs, and it conquered the whole world. It converted the pagan Roman Empire to Christ. When Catholics were distinctive, when it cost something to be a Catholic (often one's blood!), the Church flourished - and still does so in times of adversity. Increasingly, in the last few centuries in the West, it has cost very little, and Catholics have been behaving no differently than the secularized world - and have been steadily losing that world (14). Homosexuality and same sex love is the order of the day here, while churches are empty in most Catholic Churches in Europe and the US.

The guidance of the Holy Spirit does not override the normal human process of learning nor absolve Church leaders from the need of quality research. Nor does it obviate the need for sound argumentation under penalty of becoming purely "extrinsic" authority (Ajiki 138). Provided that a particular position regarding the natural law has no demonstrable connection with revelation, there is no guarantee that such a position has absolute certitude (Curran 146). Selling goes so far as to assert: "In most areas of natural morality, that church leaders enjoy no more - or less - competence than any other intelligent or wise persons on most issues" (59).

\section{OBEDIENCE}

The Church as mother and wise mother has given us the Divine Office as our daily prayer and one phrase we repeat several times a day is! "If today you hear his voice, harden not your hearts." This shows that we need to listen to the voice of the Lord of the Vineyard, Jesus Christ and that becomes the sum total of our obedience as a virtue. Obedience means in the words of Cardinal Timothy Dolan of New York: "Conforming our lives to the will of God, submitting ourselves to $\mathrm{h}$ is dominion as expressed in the Bible, in the Tradition and Magisterium of the Church, in natural Law, in the directives of our legitimate superiors, in the dictates of a wellformed conscience, and in the prompting of the Holy Spirit interpreted prudently in discernment." (75).

This virtue is so important that God expected our first parents Adam and Eve to abide by it but they tragically distorted by their sinofpride. Only Our Blessed Mother's generous obedience that corrected our first parent's disobedience.

Our Blessed Virgin Mary has now become our advocate in following the footsteps of Our Lord according to (Heb 5:7-10) 
"In the days when he was in the flesh, he offered prayers and supplications with loud tears to the one who was able to save him from death...... he learned obedience from what he suffered, and when he was made perfect, he became the source of eternal salvation for all who obey him, declared by God high priest to the order of Melchizedek."

Many priests have fears of intimacy with female gender and some even feel it would be better if they were allowed to get married and raise families of their own. But is such a decision right with my eyes and the eyes of God? The answer is no.

What is missing in our brother priests who choose to keep perpetual female friends and eventually raise children is the experience of holy union and their friendship with really good people and honest ones too. Without deep and authentic human friendship, our intimacy with God and with fellow priests leaves much to be desired. Our prayer life and the celebration of the Holy Eucharist and other Sacraments including devotions are only pretence and out of balance. Obedience is better than sacrifice. The decency of the priests today is not just wearing of the clerical dress but by demonstrating that we can be trusted with young and old female parishioners as mothers and sisters in Christ rather than wives and concubines.

\section{THE MORAL RIGHTS OF PRIESTS}

Book II of the Code of Canon Law outlines the obligations and rights of all the Christian Faithful (201-223). The first set of rights and obligations belong to the laity (224-231). Eventually, the Code

turns to the rights and obligations of clergy (273-289). Here we find three canonical rights: of association, to a vacation, and to fitting and decent remuneration. Instead of these three canonical rights,Keenan postulated six moral rights of priests . These are the right to share in the Episcopal ministry of the local ordinary, the right of association, the right to discern the proper exercise of our ministry, the right to personal development, the right to privacy, and the right to fair treatment (80). We shall briefly discuss some of these rights as proposed by Keenan.

1. The Right to Share in the Episcopal Ministry of the Local Ordinary: John Lynch, a Canon Lawyer who has written on the rights of priests, frequently asserts that "the cleric shares in the Episcopal ministry"Lynch's claim is derived from three Vatican II documents. The Decree on the Ministry and Life of Priests reads: "Priestly obedienceinspired through and through by the Spirit of cooperation, is based on the sharing of the Episcopal ministry which is conferred by the sacrament of order and the canonical mission."Similarly, the Bishop's Pastoral Office states: "All priests, whether diocesan or religious, share and exercise with the Bishop the one priesthood of Christ." Finally the Dogmatic Constitution on the Church declares: "The Bishop is to regard his priests, who are his co-workers, as sons and friends, just as Christ called his disciples no longer servants but friends."It is pertinent to note that the foundation for the moral right is found not only in the Code, its commentary, and Vatican II documents. It is also found in the rite of ordination. The first question the Bishop asks the ordainedis: "Are you resolved, with the help of the Holy Spirit, to discharge without fail the office of priesthood in the presbyteralorder as a conscientious fellow worker with the Bishops in caring for the Lord's flock?" The priest answers, "yes I am" Then, in the prayer of consecration we hear the Bishop say:

"Lord, grant also to us fellow workers, for we are weak and our need is greater. Almighty Father, grant to this servant of yours the dignity of the priesthood. Renew within him the Spirit of holiness. As a co-worker with the order of Bishops may he be faithful to the ministry that he receives from you, Lord God, and be to others a model of right conduct". 
When we hear of repeated unsuccessful attempts by clergy to meet with their Bishops,we become aware of the fact that this right is not adequately recognized. In fact, when we consider the phenomena of public by cleric, we ought to see this not so much as an indication of that right being exercised, rather as expressing frustration that the presumed right has been ignored (81).

1. The Right to Discern the Proper Exercise of Our Ministry: While there is an obligation to exercise one's priestly ministry, there is also a right to exercise that ministry according to one's particular judgment. Here I think of Priestswho must discern a variety of issues on weekly basis: whether this particular couple is actually ready to get married in the Church, whether they should preach about the way the gospel applies to this particular local issue, or how these children in this parish should be prepared for confirmation. Though by his faculties a priest exercises his ministry at the bishop's pleasure, there seems to be another claim on the priest that comes not from the Bishopdirectly but from the people whom the priest serves. If the priest is truly to promote peace and justice and

communion, it seems that in order to discern how to do so, he needs to rely on something in addition to the Bishop's particular perspective. Like other expressions of his ministry that he shares with the Bishop and with the laity, a priest's preaching calls for a conscientious integrity to witness to the gospel as he sees it expressed in his midst. This too follows from the insight of Thomas Aquinas that as we descend into a situation, we need to attend to more and more specific circumstances in order to rightly discern what is actually required (83-84).

2. The Right of Association: The right of sharing in the ministry of the Bishop leads to fostering right relations among the clergy through association. The Code , in Canon 275.1, asserts, "Since clerics all work for the same purpose, namely, the building up of the Body of Christ, they are to be united among themselves by a bond of brotherhood and prayer and strive for cooperation among themselves according to the prescripts of particular law." Immediately after this paragraph, the Code adds, "Clerics are to acknowledge and promote the mission whichthe laity, each for his or her part exercises in the Church and in the world." Associations among the clergy are intimately tied to promoting the laity's own involvement in the life of the Church. In fact, in the earlier draft of the Code , the clergy were only called to recognize the laity's mission; according to the promulgated code, they must promote it. Though canon 215 defines the right of all the Christian faithful to form associations, that is, both lay and clergy, canon 278 establishes it as the first canonical right for priests. The Code reads: "Secular clerics have the right to associate with others to pursue purposes in keeping with the clerical state." This is the first time that canon law recognized this moral right (82).

\section{IMPACT OF INFORMATION TECHNOLOGIES ON PRIESTLY MINISTRY}

Because our current synthesis of human communication is so new, education has not yet taken full advantage of it. New information technologies can lead to new opportunities, but most of us lack a systematic ability to use them. Future religious textbooks (if indeed there will be textbooks!) will surely contain CD-ROMs, integrating music, video, and animated graphics with the printed text. How can we best express the thoughts of our hearts, using collaborative, interdisciplinary methods to communicate the whole Christian message via videos, TV, CDROMS, and Web sites? While experimentation may frighten us, the best course for priests and scholars would be to try and try it now without delay. We need well articulated sound systems for our congregations for clear ministry. It must, however, be acknowledged that there are also disadvantages to information technologies on Priestly Ministry. We should endeavor to use them effectively and not shun them. 


\section{CONCLUSION}

From the time of ordination, the priest is charged with preaching the word of God, living that word in such a fashion that he preaches with his upright moral life. From human point of view, only the spiritually and emotionally mature priest can make the word of God a living, saving force in others. Pastoring, not for the faint heart, is equally ill suited for the lazy soul; it is for the adult leader, purified in the discipline of the cross. The priest is called to be such a leader he is called to be innocent without being naïve, committed without being aloof, a man of the Church without being clerical or elitist. Only the mature adult, full in the stature of grace, hope and charity meets these demands, hence there is a compelling need for ongoing moral formation of priests in order that they may constantly measure up to standard in the priestly ministry today. By taking ourselves into ascetical exercises in order to purge ourselves of our disagreeable natures, the priests of the 21 century will retreat to prayers and fasting as purifying actions before presenting the Gospel of Christ's reconciliation to the modern world. May Our Blessed Mother Mary, the Mother of all Priests abide with our human efforts inspired by the Holy Spirit, Amen. By their fruits we shall know them. We commend our brother priests of Ahiara Diocese and their friends sharing our forum to take this reflection to heart and remember that obedience to the Holy Father renews their obedience to our Priestly Ministry which we all received from Christ at ordination.

May the Mother of Christ lead them not to allow July 9 escape their allegiance to the Church they vowed to serve. Amen.

\section{Reference}

Ajiki, P. (2013). Challenges of the Christian Apostolate in Central Nigeria , Ibandan: Kraft Books Ltd, 2013.

Ajiki, P. (2010). Troubling Ethical Waters, Lagos: Sovereign Prints Nig. Ltd, 2010

Ajiki, P. (2016)."The Effects of Pentecostalism on the Catholic Moral Tradition and Teachings" in JamahhV.U (ed.)

Rediscovering and Asserting Our Catholic Identity in the Face of Pentecostalism pp. 133-183, 2016.

Curran, C. E. The Moral Theology of Pope John Paul

Washington D.C: (20005). Georgetown University Press, 2005.

Cozzens, D.B. (2000). The Changing Face of the Priesthood. Minnesota: The Liturgical Press, 2000.

Dolan, T. M. (2000). Priests for the Third Millennium . Indiana: Our Sunday Visitor Publishing Division, 2000.

Johnson, M. Moral (1993). Imagination . Chicago: University of Chicago Press, 1993.

Kreeft, P. (2001). Some Fundamental Principles of Catholic of Morality. New Haven: Knights of Columbus Supreme Council, 2001.

Kreeft, P. (2001)The Essence of Catholic Morality. New Haven: Knights of Columbus Supreme Council, 2001.

Keenan, J. (2006). “The Moral Rights of Priests" in Dietrich Donald (ed.) Priests for the 21 Century, New York: The Crossroad Publishing Company,2006.

Keenan, J. (2004). Moral Wisdom, Lessons and Text from the Catholic Traditions. New York: A Sheed and Ward Book, 2004.

Lewis, B. Conscience and the Teaching Magisterium on Morality, accessed from: http://aejt.com.au/data/assets/pdf_file/0020/107525/BLewis_Conscience andMagisterium.pdf

Rigali, N. (1988). Moral Theology and the Magisterium. Horizons 15 (Spring 1988),

White, J.E. (2012). Contemporary Moral Problems: War, Terrorism, Torture and Assassinations, Boston: Cengage Learning, 2012. 